\title{
The Persistence of Deltamethrin in Malaysian Agricultural Soils
}

(Kekekalan Deltametrin dalam Tanah Pertanian Malaysia)

\author{
B.S. ISMAIL*, M. MAZLINDA \& M.A. TAYEB
}

\begin{abstract}
Studies on the persistence and dissipation of deltamethrin $\left(\mathrm{C}_{22} \mathrm{H}_{19} \mathrm{Br}_{2} \mathrm{NO}_{3}\right)$ in two types of soil, namely peat and silty clay were conducted under laboratory conditions. The analysis was done using a gas chromatography (GC) equipped with an electron capture detector (ECD). The dissipation rate of deltamethrin was faster in silty clay soil than in peat soil at $25^{\circ} \mathrm{C}$. When the temperature was increased from 25 to $35^{\circ} \mathrm{C}$, the half-life of deltamethrin decreased by $32.53 \%$ in peat soil and $22.9 \%$ in the silty clay soil in the presence of light. When the same experiment was conducted in the dark, the decrease in the half-life of deltamethrin was $27.9 \%$ in peat soil and $22.5 \%$ in silty clay soil. When the soil moisture content was increased from 40 to $60 \%$, the half-life of deltamethrin decreased by 50.7 and $19.75 \%$ in peat soil and silty clay soil, respectively. A significant degradation rate of deltamethrin was observed in non-autoclaved soil compared with that in autoclaved soil where the half-life was reduced by $76.05 \%$ in peat soil and $59.21 \%$ in silty clay soil. The results showed that the degradation rate of deltamethrin in soil had a direct relationship with the microbial activity in the soil.
\end{abstract}

Keywords: Deltamethrin; half-life; microbial activity; persistence; soils

ABSTRAK

Kajian ke atas kekekalan dan kadar resapan deltametrin $\left(\mathrm{C}_{22} \mathrm{H}_{19} \mathrm{Br}_{2} \mathrm{NO}_{3}\right)$ dalam dua jenis tanah (tanah gambut dan tanah liat berkelodak) telah dijalankan dalam keadaan makmal. Analisis ini dilakukan dengan menggunakan gas kromatografi $(G C)$ dilengkapi dengan elektron pengesan tangkapan (ECD). Kadar resapan deltametrin adalah lebih tinggi dalam tanah liat berkelodak daripada tanah gambut pada $25^{\circ} \mathrm{C}$. Apabila suhu meningkat antara 25 hingga $35^{\circ} \mathrm{C}$, separuh hayat deltametrin menurun sebanyak $32.53 \%$ di dalam tanah gambut dan 22.9\% dalam tanah liat berkelodak dengan kehadiran cahaya. Apabila kajian yang sama dijalankan dalam keadaan gelap, penurunan separuh hayat deltametrin adalah lebih tinggi dengan $27.9 \%$ di dalam tanah gambut dan $22.5 \%$ dalam tanah liat berkelodak. Apabila kelembapan tanah meningkat daripada 40 kepada 60\%, separuh hayat deltametrin masing-masing menurun kepada 50.7 dan $19.75 \%$ dalam tanah gambut dan dalam tanah liat berkelodak. Kadar penurunan deltametrin yang ketara diperhatikan di dalam tanah bukan autoklaf berbanding tanah autoklaf dengan separuh hayat telah dikurangkan kepada $76.05 \%$ di dalam tanah gambut dan 59.21\% dalam tanah liat berkelodak. Hasil kajian menunjukkan bahawa kadar penguraian deltametrin dalam tanah mempunyai hubungan yang kukuh dengan aktiviti mikrob di dalam tanah.

Kata kunci: Aktiviti mikrob; deltametrin; kekekalan; separuh hayat; tanah

\section{INTRODUCTION}

In practice, pesticides are usually applied simultaneously or separately for crop protection. Deltamethrin is a pyrethroid composed of a single isomer of 8 streamers selectively prepared by the esterification of [1R,3R or cis] -2,2-dimethyl-3-(2,2-dibromovinyl) cyclopropanecarboxylic acid with (alpha $\mathrm{S}$ ) -or (+) -alpha-cyano-3-phenoxybenzylalchohol or by selective recrystallization of the racemic esters obtained by esterification of the (1R, 3R or cis) -acid with the racemic or alpha R, alphas, or alpha RS + or-] -alcohol. It disrupts the nervous system of insects through dermal contact and digestion of the synthetic pyrethroid and results in the death of the insects (Khan et al. 1988). Since 1974, deltamethrin has been the most popular and widely used insecticide in the world and has become very popular with pest control operators as well as other individuals
(Ismail \& Dan-Lin 2003). The many uses of deltamethrin ranged from agricultural crop protection to household pest control.

Due to the environmental significance of pesticides and their residue, a thorough understanding of the physical, biological and chemical effects is important (Xuang et al. 2000). Approximately less than $0.1 \%$ of the applied pesticide reaches the target pest, leaving the bulk to affect the environment (Ardley 1999). Deltamethrin is not mobile in the environment because of its strong adsorption of particles, its solubility in water and very low rate of application. However, it still presents risks to the ecosystem into which it is applied (Bhanu et al.2011). Deltamethrin is widely used in agriculture because of its persistence, residual activity and low toxicity to mammals (Lawskowski 2002). Deltamethrin has little potential to leach into groundwater due to its strong tendency to bind 
onto soil organic matter (Tomlin 2006). The half-life under aerobic laboratory conditions for deltamethrin in sandy loam or silty loam soils ranges from 11-72 days (Tomlin 2006; WHO 1990). Deltamethrin has a very short half-life in water ( 8 to $48 \mathrm{~h}$ ) and degrades to decamethrinic acid, as well as to its less active isomers. Deltamethrin degrades via hydrolysis, photolysis and microbial action. It is not susceptible to photo-oxidation and is more persistent in soils with a high clay or organic matter content (Roberts \& Hutson 1999). Under anaerobic soil conditions, the half-life for deltamethrin ranges from 31-36 days (Tomlin 2006). Only a few studies have been conducted on the persistence of deltamethrin in the environment (Huntsman-Mapila 2002; Tomlin 2006). Huntsman-Mapila (2002) reported that deltamethrin accumulated in peat soil and exhibited variable degradation rates which consequently affected its degree of accumulation.

Persistence and degradation of deltamethrin in Mexican soil was reported by Yanez et al. (2002). In Malaysia, there is little information on the persistence of deltamethrin in local soils. The climatic conditions in tropical areas such as in Malaysia are different from those of the temperate countries. Therefore, more information is urgently needed regarding the behavior of this compound under the Malaysian climate. The present study was carried out to investigate the persistence of deltamethrin in two Malaysian soil types and to observe environmental effects on the half-life of the compound.

In the natural environment, the primary processes of pyrethroid degradation in the soil are mainly photo degradation and biodegradation, in either alkaline or neutral $(\mathrm{pH})$ water with limited light intensity. The main mode of deltamethrin degradation includes hydrolysis of ester bonds and oxidation of the acid and alcohol functional groups (Vieria 2008). The rate of degradation depends on the pyrethroid, soil type, climate, species of microbes present and the size of their populations. According to Sing et al. (2002), deltamethrin is degraded by bacteria of the Micrococcus sp. In oxygen cultures, the half-life of these microorganisms ranges from 21 to 28 days. Previous reports have indicated that deltamethrin has a half-life of 3-8 weeks in mineral soils (Chapman et al. 1981; Miyamoto \& Mikami 1983). Hill (1985) reported that of the phyrethroids used commercially, fenvalerate and deltamethrin are the most persistent, especially in soil of high organic matter content.

Due to the lack of data on the degradation of deltamethrin under tropical conditions, such as those in
Malaysia, a study was conducted to investigate the behavior of deltamethrin under such conditions. The objective of the project was to assess the effect of environmental factors (i.e. soil moisture, temperature and microbial activity) on the degradation of deltamethrin in two types of Malaysian soil namely, peat and silty clay.

\section{MATERIALS AND METHODS}

\section{CHEMICALS USED IN THE STUDY}

Commercial grade deltamethrin (Dencis ${ }^{\circledR} 12.35$ ai/L) was supplied by AGROVO Sdn. Bhd (Malaysia), while analytical grade deltamethrin (99.9\% purity) was obtained from Chem. Service (SUPELCO, USA) for the calibration curve. The properties of deltamethrin are shown in Table 1. By diluting the commercial grade deltamethrin with distilled water, a stock solution of $100 \mu \mathrm{g} / \mathrm{mL}$ was prepared. By appropriate dilution of the standard stock solution of $100 \mu \mathrm{g} / \mathrm{mL}$ with HPLC grade hexane, working standard solutions of $2.0-10.0 \mu \mathrm{m} / \mathrm{mL}$ was prepared. All standard stock solutions were freshly prepared and stored at $-4^{\circ} \mathrm{C}$.

\section{SOIL COLLECTION AND ANALYSIS}

The soil types used in the study were peat and silty clay, representing soil from the vegetable growing areas of the Kuala Selangor Agriculture Department and Kampong Yu in Selangor. The soil physico-chemical analysis was done in the soil testing laboratory at Universiti Kebangsaan Malaysia (UKM) Bangi in Selangor, Malaysia. The samples were air-dried, gently crumbled and sieved through $2 \mathrm{~mm}$ mesh and used immediately for the study. Samples were collected from the surface layer $(0-15 \mathrm{~cm})$ depth. In this experiment, 54 samples were analysed and each sample replicated thrice. All samples were concealed in black polyethylene bags and stored at $-4^{\circ} \mathrm{C}$. According to Bao (2000), the methods of analysis for soil characteristics were diverse as shown in Table 2.

\section{EXTRACTION OF SOIL SAMPLES}

About $20.0 \mathrm{~g}$ soil samples were weighed Eclips $^{\mathrm{TM}}$ analytical balance, 11121-30, France) and placed into 250 $\mathrm{mL}$ volumetric flasks. Then $150 \mathrm{~mL}$ water was assimilated with acetonitrile (water: acetonitrile, 1:2) and the mixture was shaken on a horizontal shaker for $30 \mathrm{~min}$ ( $240 \mathrm{rpm}$ ). The experiment was done in triplicates. Before transferring

TABLE 1. Properties of deltamethrin

\begin{tabular}{ll}
\hline Parameter & Deltamethrin \\
\hline CAS No. & $52918-63-5$ \\
Molecular weight & $505.2 \mathrm{~g} / \mathrm{mol}$ \\
Number of isomers & 1 \\
Solubility in water $(\mu \mathrm{m} / \mathrm{L})$ & Ranges from $0.002-0.0002 \mathrm{mg} / \mathrm{L}$ at $250^{\circ} \mathrm{C}$ \\
Log Kow & 6.1 \\
\hline
\end{tabular}

Data quoted from Bruun Hansen (2002). Kow: octanol/water partition coefficient 
TABLE 2. Physico - chemical properties of soil

\begin{tabular}{lcc}
\hline Parameter & Peat soil & Silty clay soil \\
\hline $\mathrm{pH}$ & 4.16 & 5.40 \\
$\%$ Organic matter & 79.96 & 8.52 \\
Cation-exchange capacity (CEC) $(\mathrm{meq} / 100 \mathrm{~g})$ & 33.82 & 202.6 \\
Sand $(\%)$ & 3.00 & 2.85 \\
Silt $(\%)$ & - & 46.10 \\
Clay $(\%)$ & - & 51.05 \\
$\%$ Water content & 52 & 29.1 \\
\hline
\end{tabular}

the mixture into the separating funnel, $20 \mathrm{~mL}$ hexane was added and then left for $60 \mathrm{~min}$. This was followed by shaking for $1 \mathrm{~min}$ and then $50 \mathrm{~mL}$ of $4 \% \mathrm{NaCl}$ was added in the extraction process. The hexane layer was filtered by $40 \mathrm{~g}$ of $\mathrm{Na}_{2} \mathrm{SO}_{4}$ in a glass column, after transferring the water layer. The clear supernatant was collected and the particulates were removed by filtering through $0.45 \mu \mathrm{m}$ pore size regenerated cellulose membrane. The extract was evaporated to dryness in a stream of nitrogen gas and finally dissolved in $1 \mathrm{~mL}$ of hexane for GC-ECD analysis.

\section{RECOVERY STUDY}

The efficiency of the extraction procedure for deltamethrin was evaluated using peat and silty clay soils. This was done by spiking the soil samples with deltamethrin and extracting the pesticides as described earlier. The concentrations used for the recovery study were 5,25 and $50 \mathrm{ppm}$ and $50 \mathrm{~g}$ of soil was spiked with the above three concentrations. The $50 \mathrm{~g}$ soil sample was spiked with 10 $\mathrm{mL}$ deltamethrin and after mixing, $20 \mathrm{~g}$ of the soil was used for extracting the deltamethrin residue.

\section{EFFECTS OF TEMPERATURE ON THE DEGRADATION OF DELTAMETHRIN}

In the degradation process, soil temperature could have a direct effect on the phase distribution of pesticides. The study was carried out under laboratory conditions. Air dried peat and silty clay soils $(3.6 \mathrm{~kg})$ were treated with deltamethrin. The final concentration of the treated soil was $50 \mathrm{mg} / \mathrm{kg}$. Control samples were prepared the same way. After proper blending, $50 \mathrm{~g}$ portions of the treated soil samples were concealed in 72 polyethylene bags. The polyethylene bags were divided into 4 groups and incubated (MSE Laboratory Incubators $1249 \times 901$, UK) either at 25 or $35^{\circ} \mathrm{C}$. For every temperature treatment, the bags were placed under dark and light conditions. The soil moisture level was maintained at field capacity through spraying water and weighing after every 5 days. A bag (50 g) of the soil sample for each treatment level was concealed under $0^{\circ} \mathrm{C}$ from week 1 to 16 . The experimental design was a randomized block design with 3 replications. All samples were dried overnight under open air after every week of incubation, placed into individual flask and subjected to the extraction process before gas chromatographic analysis. The half-lives of deltamethrin were derived individually from the slope of the line. The best fit was calculated $(\mathrm{k}$ $=0.0102$ peat soil and 0.0188 silty clay soil) by the linear regression analysis of the logarithm of the remaining concentration against that at the time of incubation.

\section{EFFECT OF MOISTURE ON THE DEGRADATION OF DELTAMETHRIN}

Air-dried peat and silty clay soil samples (2.7 kg each) were treated to obtain a final concentration of $50 \mathrm{mg} / \mathrm{kg}$. Initial moisture samples were divided into 3 groups and another two samples added had 40 and $60 \%$ moisture content. Samples of the treated soil were kept in each of the 54 polythene bags after proper mixing. The samples were then incubated at 25 and $35^{\circ} \mathrm{C}$. The sample bags were weighed weekly and watered when necessary. The initial moisture level was maintained by adding distilled water. Before determination of the residue level using the $\mathrm{GC}, 20 \mathrm{~g}$ soil samples were placed into flasks and treated as described before.

\section{EFFECT OF AUTOCLAVING ON THE DEGRADATION OF DELTAMETHRIN}

Two groups of $1.8 \mathrm{~kg}$ each of peat and silty clay soils were air dried and autoclaved (ESCHMAW, SES 220, Japan, pressure $1 \mathrm{psi}$, temperature $121^{\circ} \mathrm{C}$, duration $60 \mathrm{~min}$ ). Then $900 \mathrm{~g}$ of soil was treated with deltamethrin to get a final concentration of $50 \mathrm{mg} / \mathrm{kg}$ and concealed in 36 polyethylene bags. The polyethylene bags were weighed every week and watered whenever necessary. By adding water the initial moisture content was maintained. At the end of every week all samples were thawed, air-dried overnight and $20 \mathrm{~g}$ of each sample was placed into a flask and subjected to the extraction process before GC-ECD analysis.

\section{STATISTICAL ANALYSIS}

All the experiments were carried out using the randomized block design with three replications. All data were statistically analysed with a single factor analysis of variance (ANOVA) at the significance level of $p \leq 0.05$.

\section{GC CONDITION}

The extracted residues were estimated using an Altech 4890 (US) gas chromatograph equipped with an electron 
capture detector (ECD) manual injector and the non-polar capillary column HP-5 was cross linked with 5\% Phenyl Methyl Siloxane column $(30.0 \mathrm{~m} \times 0.32 \mu \mathrm{m}$ id, $0.25 \mu \mathrm{m}$ thickness films). The operating temperatures were $300^{\circ} \mathrm{C}$ for the detector and $280^{\circ} \mathrm{C}$ for the port while the oven was programmed initially at $205^{\circ} \mathrm{C}$ for $2 \mathrm{~min}$ and then the temperature was increased to $300^{\circ} \mathrm{C}$ at the rate of $30^{\circ} \mathrm{C} /$ $\mathrm{min}$ and maintained for $4 \mathrm{~min}$. The carrier gas was nitrogen $\left(\mathrm{N}_{2}, 99 \%\right)$ with a flow rate of $1 \mathrm{~mL} / \mathrm{min}$. The volume of injection was $1 \mu \mathrm{L}$. There were three replicates and each concentration was injected twice. Under these conditions the retention time of deltamethrin was $18.2 \mathrm{~min}$.

\section{RESULTS AND DISCUSSION}

Table 2 shows the physico-chemical characteristics of the two soil types, namely peat and silty clay soil. It should be noted that the peat soil contains higher organic matter content $(79.96 \%)$ than silty clay soil $(8.52 \%)$. In contrast, the CEC of silty clay soil was higher than that of the peat soil.

The preliminary results of the recovery studies of deltamethrin in the two soil types are shown in Table 3. The percentage recovery of deltamethrin was the highest at $50 \mathrm{ppm}$ in the peat soil and silty clay soil samples. The highest percentage recovery obtained for deltamethrin in the silty clay and peat soil was $91.04 \%$ and $92.74 \%$, respectively at $50 \mathrm{ppm}$ concentration. At 5 and $25 \mathrm{ppm}$ concentrations, the percentage recovery was the lowest ranging from $89.36-84.59 \%$ for both types of soil.

Degradation of deltamethrin was slightly higher in the silty clay which has lower organic matter content $(8.52 \%)$ than the peat soil $(79.96 \%)$ irrespective of whether the samples were under light or in darkness. Organic matter is known to be closely associated with the inorganic soil components and it provides a large percentage of the surface area in soils because of its porous molecular structure (Felsot \& Dahm 1979). The soil organic matter progressively loses oxygen by a qualification process and thus the chemical functions, adsorb the insecticides and increase their soil persistence (Rouchaud et al. 1996). Hill (1985) reported that dissipation of pyrethroids was slower with a $50 \%$ reduction from initial concentration in 20 weeks for soil with high organic matter content. These results are in agreement with the above reports, which showed that the half-life of deltamethrin is slightly longer in organic soil compared with that in non-organic soil.

Since it was assumed that degradation of deltamethrin followed first-order kinetics. Table 4 shows the effects of temperature on the degradation rate of deltamethrin in the two soil types studied. A similar pattern of the half-life of deltamethrin was observed when the temperature was increased from 25 to $35^{\circ} \mathrm{C}$. The half-life decreased from 5.93 to 4.27 weeks in peat soil and from 4.40 to 3.41 weeks in silty clay soil under dark condition. Under the light, the half-life was reduced from 5.44 to 3.67 weeks and from 4.32 to 3.24 weeks in peat soil and silty clay soil, respectively. Increased degradation rates of many pesticides at higher temperatures are well documented (Ferrel \& Vencill 2003). There is evidence that pesticide degradation rates increased at higher temperatures which, in most cases, probably reflected to increased biological activity. The rate of breakdown is influenced by the intensity and spectrum of sunlight, length of exposure and properties of the pesticide. The photo-degradation of organic compounds in the soil is affected by many factors. Balmer et al. (2000) found that soil particle size, mineral composition, light absorption characteristics and moisture content affected the nature of soil photoreactions of pesticides. Because light penetration into soils is very limited (Cavoski et

TABLE 3. Recovery study of deltamethrin from soil

\begin{tabular}{ccc}
\hline Concentration $(\mathrm{ppm})$ & $\begin{array}{c}\text { Peat soil } \\
n=4\end{array}$ & $\begin{array}{c}\text { Silty clay soil } \\
n=4\end{array}$ \\
\hline 5 & $88.68 \pm 0.04$ & $89.36 \pm 0.01$ \\
25 & $84.59 \pm 0.02$ & $85.52 \pm 0.05$ \\
50 & $92.74 \pm 0.04$ & $91.04 \pm 0.02$ \\
Least significant difference $\mathrm{LSD}_{0.05}$ & 6.70 & 6.02 \\
\hline
\end{tabular}

TABLE 4. Degradation rate coefficients (k), correlation coefficients (r) and half-life (weeks) of deltamethrin at different temperatures in the soils used

\begin{tabular}{ccccccc}
\hline \multirow{2}{*}{$\begin{array}{c}\text { Temperature } \\
\left({ }^{\circ} \mathrm{C}\right)\end{array}$} & \multicolumn{3}{c}{ Peat soil } & \multicolumn{3}{c}{ Silty clay soil } \\
\cline { 2 - 7 } & $r^{2}$ & $\mathrm{k}$ & $\mathrm{t}_{1 / 2}$ & $r^{2}$ & $\mathrm{k}$ & $\mathrm{t}_{1 / 2}$ \\
\hline 25 (dark) & 0.9901 & 0.1168 & 5.93 & 0.9928 & 0.1576 & 4.40 \\
25 (light) & 0.9728 & 0.1273 & 5.44 & 0.9348 & 0.1603 & 4.32 \\
35 (dark) & 0.9326 & 0.1620 & 4.27 & 0.9413 & 0.2033 & 3.41 \\
35 (light) & 0.9242 & 0.1886 & 3.67 & 0.9149 & 0.2138 & 3.24 \\
LSD $_{0.05}$ & 0.0052 & 0.0102 & 0.36 & 0.0257 & 0.0188 & 0.36 \\
\hline
\end{tabular}


al. 2007; Fan et al. 2005) and is wavelength dependent, the fraction of the total compound actually exposed to light depends on the type of soil, the thickness of the soil layer and the light absorption spectrum of the compound. Since temperature and humidity strongly influence the compound sorption behavior and rate of disappearance of the compound from the soil (Graebing \& Chib 2004), these parameters also need to be considered. Photolysis rates and photo-transformation products are actually dependent on the intensity and wavelength distribution of the light used (Konstantinou et al. 2001).

In peat soil, the half-life of deltamethrin was comparatively shorter than that in silty clay soil with increasing soil moisture content (Table 5). When the soil moisture content increased from 40 to $60 \%$, the half-life of deltamethrin reduced from 6.59 to 3.25 weeks and from 5.72 to 4.59 weeks in peat and silty clay soil, respectively. At initial soil moisture, the same trend was observed where the half-life in peat and silty clay soil was 3.36 weeks and 6.31 weeks, respectively and the average reduction of the half-life of deltamethrin in peat soil was 50.68 and $19.76 \%$ in silty clay.

In general, pesticide degradation has been found to increase with increasing soil moisture content (Dungan et al. 2003; Walker et al. 1992). Based on the average halflife in the soils studied, it was observed that the half-life of deltamethrin is longer at a temperature of $25^{\circ} \mathrm{C}$ than at $35^{\circ} \mathrm{C}$ and at $40 \%$ than at $60 \%$ soil moisture content. An increase in the rate of insecticide degradation at higher soil moisture content is expected since higher moisture levels hinder insecticide adsorption onto soil particles, making the insecticide molecules more readily available for degradation by soil microbes (Ismail \& Dan-Lin 2003). These results are similar to previous reports showing that moisture and temperature have an influence on the degradation rate of cyfluthrin and permethrin, which belong to the pyrethroid group of insecticides (Skidmore 1994; Smith et al. 1995).

In non-autoclaved peat soil, the half-life of deltamethrin was comparatively much shorter than that in the silty clay soil (Table 6). The half-life in the non-autoclaved peat soil was 3.36 weeks and 6.31 weeks in silty clay. However, the half-life was slightly longer in autoclaved soil for both the soil types studied. In peat soil, the half-life was 14.3 and 3.36 weeks in autoclave and non-autoclave soil, respectively, while in the silty clay soil the half-life was 15.47 and 6.31, respectively. Degradation of deltamethrin was faster in non-autoclaved than in autoclaved soil, which meant that $50 \%$ of the degradation could be attributed to biological activities. The degradation of deltamethrin in soil is a microbial process and the main degradation pathway in soil can be described by ester cleavage, followed by oxidation leading to the formation of calcium bromide $\left(\mathrm{CaBr}_{2}\right)$ and azelaic acid. Both these metabolites mineralized relatively quickly to $\mathrm{CO} 2$. The only major but transient soil metabolite is $\mathrm{CaBr}_{2}$, which was formed under laboratory conditions in amounts $>10 \%$ of the applied radioactivity. It degrades very rapidly with the half-life ranging from $<1$ day to 12 days. The indigenous microorganisms in the soil play an important role in the degradation of pesticides. The degradation difference of isomers might be due to selective degradation by soil microorganisms occurring at specific environments (Ma et al. 2005). The same trend of degradation of a pesticide (imazapyr) was reported by Wang et al. (2005). Similar results were also obtained by Lee (1985), Miyamoto and Mikami (1983) and Okhawa et al. (1978) who found that degradation of other pyrethroid groups, on an average was higher in non-autoclaved soil than in autoclaved soil. Khan et al. (1988) reported that the microbial population of soil treated with deltamethrin utilized deltamethrin as a sole source of carbon and energy. In the absence of bacterial

TABLE 5. Degradation rate coefficients (k), correlation coefficients ( $\mathrm{r}$ ) and half-life (weeks) of deltamethrin at different soil moisture in the soils used

\begin{tabular}{lcccccc}
\hline Soil moisture & \multicolumn{3}{c}{ Peat soil } & \multicolumn{3}{c}{ Silty clay soil } \\
\cline { 2 - 7 } & $r^{2}$ & $\mathrm{k}$ & $\mathrm{t}_{1 / 2}$ & $r^{2}$ & $\mathrm{k}$ & $\mathrm{t}_{1 / 2}$ \\
\hline Initial & 0.9353 & 0.2065 & 3.36 & 0.9584 & 0.1097 & 6.31 \\
$40 \%$ & 0.9155 & 0.1052 & 6.59 & 0.9374 & 0.1211 & 5.72 \\
$60 \%$ & 0.9292 & 0.2130 & 3.25 & 0.9258 & 0.1510 & 4.59 \\
LSD $_{0.05}$ & 0.0449 & 0.0031 & 0.06 & 0.0285 & 0.0105 & 0.42 \\
\hline
\end{tabular}

TABLE 6. Degradation rate coefficients (k), correlation coefficients (r) and half-life (weeks) of deltamethrin in autoclaved and non-autoclaved soils

\begin{tabular}{|c|c|c|c|c|c|c|}
\hline & \multicolumn{3}{|c|}{ Peat soil } & \multicolumn{3}{|c|}{ Silty clay soil } \\
\hline & $r^{2}$ & $\mathrm{k}$ & $\mathrm{t}_{1 / 2}$ & $r^{2}$ & $\mathrm{k}$ & $\mathrm{t}_{1 / 2}$ \\
\hline Non-autoclaved & 0.9353 & 0.2065 & 3.36 & 0.9584 & 0.1097 & 6.31 \\
\hline Autoclaved & 0.8821 & 0.0494 & 14.03 & 0.9165 & 0.0448 & 15.47 \\
\hline $\mathrm{LSD}_{0.05}$ & 0.0698 & 0.0052 & 0.19 & 0.0204 & 0.008 & 0.50 \\
\hline
\end{tabular}


isolates, nearly complete quantitative recovery (90-97\%) of deltamethrin was obtained.

The $\mathrm{pH}$ of the soils may have affected the degradation of the herbicide but this test was not carried out in the study. Previous report had shown that $\mathrm{pH}$ affected the degradation of deltamethrin in peat and silty clay soils (Racke 2001). The hydrolysis of deltamethrin is $\mathrm{pH}$ dependent (Racke 2001) whereby, the degradation of deltamethrin was higher at lower $\mathrm{pH}$ (3.0) for both soil types. Many reports (Freed $\&$ Chiou 1979) have also indicated more rapid hydrolysis under alkaline conditions at higher $\mathrm{pH}(7.0-8.5)$. In this study, the degradation was low at $\mathrm{pH}(10.0)$ as predicted due to its higher alkaline condition.

Many factors affect the dissipation and persistence of pesticides in the soil environment. Environmental factors such as temperature, soil moisture, microbial activity and properties, as well as the particular characteristics of the pesticides, such as solubility, have a great influence on the persistence and mobility of most pesticides (Ismail \& Kalithasan 1997; Liu et al. 2010). In conclusion, temperature, soil moisture content and microbial activity affect the degradation of deltamethrin in both the soil types studied.

\section{CONCLUSION}

Soil moisture content and temperature are the two most important factors that affect the degradation of deltamethrin in both the soil types studied. However, microorganisms in the soil also play an important role in the degradation of deltamethrin as seen from the results obtained. The results from the laboratory studies can be extrapolated to field conditions but requires further consideration because other factors (soil texture, soil composition and rainfall) could also influence the half-life of an agrochemical.

\section{REFERENCES}

Ardley, J.H. 1999. Pesticide considerations on environmental concern. Agricultural Sciences 12(2): 21-24.

Balmer, M.E., Goss, K.U. \& Schwarzenbach, R.P. 2000. Photolytic transformation of organic pollutants on soil surfaces - experimental approach. Environmental Science Technology 34: 1240-1246.

Bao, S.D. 2000. Soil and Agricultural Chemistry Analysis. Bejing: China Agriculture Press.

Bhanu, S., Archana, S., Ajay, K., Bhatt, J.L., Bajpai, S.P., Singh, P.S. \& Vandana, B. 2011. Impact of deltamethrin on environment, use as an insecticide and its bacterial degradation: A preliminary study. International Journal Environment Sciences 1(5): 977-985.

Bruun Hansen, H.C. 2002. Sorption of lambda cyhalothrin, deltamethrin and fenvalerate to quartz, corundum, kaolinite and montmorillonite [J]. Chemosphere 49(10): 1285-1294.

Chapman, R.A., Tu, C.M., Harris, C.S. \& Cole, C. 1981. Persistence of five pyrethroid insecticides in sterile and natural mineral and organic soil. Bulletin of Environmental Contamination and Toxicology 26: 513-519.

Cavoski, I., Caboni, P., Sarais, G., Cabras, P. \& Miano, T. 2007. Photodegradation of rotenone in soils under environmental conditions. Journal of Agricultural and Food Chemistry 55: 7069-7074.

Dungan, R.S., Gan, J. \& Yates, S.R. 2003. Accelerated degradation of methyl isothiocyanate in soil. Water, Air and Soil Pollution 142: 299-310.

Fan, X.Z., Lu, B. \& Gonj, A.J. 2005. Dynamics of solar light photodegradation behaviour of atrazine on soil surface. Journal of Hazardous Materials 117: 75-79.

Felsot, A. \& Dahm, P.A. 1979. Sorption of organophosphorus and carbamate insecticides by soil. Journal of Agricultural and Food Chemistry 27(3): 557-563.

Ferrel, J.A. \& Vencill, W.K. 2003. Flumioxazin soil persistence and mineralisation in laboratory experiments. Journal of Agricultural and Food Chemistry 51(16): 4719-4721.

Freed, V.H. \& Chiou, C.T. 1979. Degradation of selected organophosphate pesticides in soil and water. Journal of Agricultural and Food Chemistry 27: 706-708.

Graebing, P. \& Chib, J.S. 2004. Soil photolysis in a moisture and temperature controlled environment 2 Insecticides. Journal of Agricultural and Food Chemistry 52: 2606-2614.

Hill, I.R. 1985. Pyrethroid residues in soil and aquatic environments. Pesticide Science 16: 192-215.

Huntsman-mapila,P. 2002. Fate of deltamethrin. In Environmental Monitoring of Tsetse Aerial Spraying, edited by Perkins, J.S. \& Ramberg, L. Botswana: Ministry of Agriculture.

Ismail, B.S. \& Dan-Lin, O. 2003. Effects of temperature and moisture on the persistence of terbuthylazine in two Malaysia agricultural soils. Plant Protection Quarterly 18(2): 48-51.

Ismail, B.S. \& Kalithasan, K. 1997. Effects of repeated application on persistence and downward movement of four herbicides in soil. Australian Journal of Soil Research 35: 503-513.

Khan, S.U., Bekhi, R.M., Tapping, R.I. \& Akhbar, M.H. 1988. Deltamethrin residues in an organic soil under laboratory conditions and its degradation by bacterial strain. Journal of Agricultural and Food Chemistry 36: 636-638.

Konstantinou, I.K., Zarkadis, A.K. \& Albanis, T.A. 2001. Photodegradation of selected herbicides in various natural waters and soils under environmental conditions. Journal of Environmental Quality 30: 121-130.

Lawskowski, D.A. 2002. Physical and chemical properties of pyrethroid. Reviews of Environmental Contamination and Toxicology 174: 49.

Lee, P.W. 1985. Fate of fenvalerate (Pydrin insecticide) in the soil environment. Journal of Agricultural and Food Chemistry 33: 993-998.

Liu, P., Liu, Y., Liu, Q. \& Liu J. 2010. Photodegradation mechanism of deltamethrin and fenvalerate. Journal of Environmental Sciences 22(7): 1123-1128.

Ma, Y., Xu, C., Chen, S., Wen, Y. \& Liu, W. 2005. Enantioselective degradation of 2, 4, 2-dichlorprop methyl ester by sediment bacteria. Journal of Environmental Science 26(4): 152-155.

Miyamoto, J. \& Mikami, N. 1983. Degradation of pyrethroid insecticides in the field. In Pesticide Chemistry: Human Welfare and the Environment, edited by Takahashi, N., Yoshioka, H. \& Misato, T. New York: Pergamon Press. pp. 193-200.

Okhawa, H., Nambu, K., Inui, H. \& Miyamoto, J. 1978. Metabolic fate of fenvalerate microorganisms. Pesticide Science 129: 329-330.

Racke, K.D. 2001. Environmental Fate of Chloropyrifos. Rev. of Environ. Contam. Toxicol. New York: Springer-Verlag.

Roberts, T. \& Hutson, D. 1999. Metabolic Pathways of Agrochemicals. Part 2: Insecticides and Fungicides. 1st 
ed. Cambridge, UK: The Royal Society of Chemistry. pp. 638-644.

Rouchaud, J., Thirion, A., Wauters, A., Van de Steene, F., Benoit, F., Ceustermans, N., Gillet, J., Marchand, S. \& Vanparys, L. 1996. Effects of fertilizer on insecticides adsorption and biodegradation in crop soils. Archives of Environmental Contamination and Toxicology 31: 98-106.

Sing, B.K., Walker, A. \& Wright, D.J. 2002. Persistence of chloropyriphos, fenamiphos, chlorothelonil and pendimethalin in soil and their effects on soil microbial characteristics. Bulletin of Environmental Contamination and Toxicology 69: 181-188.

Skidmore, M.W. 1994. Influence of application methods on the degradation of permethrin in laboratory, soil aerobic metabolism studies. Pesticide Science 42: 101-107.

Smith, S., Willis, G.H. \& Cooper, C.M. 1995. Cyfluthrin persistence in soil as affected by moisture, organic matter and redox potential. Journal of Agricultural and Food Chemistry 29: 1122-1125.

Tomlin, C.D.S. 2006. The Pesticide Manual: A World Compendium. 14th ed. Farnham, UK: British Crop Protection Council. pp. 286-287.

Vieria, S.S. 2008. Effects of pesticides used in soya bean crops to the egg parasitoidtrichogrammapretiosum. Ciência Rural, Santa Maria 389(6): 1495-1503.

Walker, A., Moon, Y.H. \& Welch, S.J. 1992. Influence of temperature, soil moisture and soil characteristics on the persistence of alachlor. Pesticide Science 35: 109-116.
Wang, X.D., Zhou, S.M., Wang, H.L. \& Fan, D.F. 2005 Biodegradation of imazapyr in typical soils in Zhejiang Province, China. Journal of Environmental Science (China) 17(4): 593-597.

WHO. 1990. Environmental Health Criteria-97. Deltamethrin: International Programmes on Chemical Safety. WHO: Geneva, Switzerland. pp.1-33.

Xuang, X., Le, L.S. \& Nakatsu, C. 2000. Impact of animal waste lagoon effluents on chloropyriphos degradation in soils. Environmental Toxicology and Chemistry 19: 2864-2870.

Yanez, L., Ortiz-Perez, D., Barts Le Borja-Aburto, V.H. \& DiazBrriga, F. 2002. Levels of dichlorodiphenyltrichloroethane and deltamethrin in humans and environmental samples in malaria's areas of Mexico. Environmental Research, Section A 88: 174.

School of Environmental and Natural Resource Sciences Faculty of Science and Technology

Universiti Kebangsaan Malaysia 43600 Bangi, Selangor Darul Ehsan Malaysia

*Corresponding author; email: ismail@ukm.edu.my

Received: 24 September 2013

Accepted: 24 June 2014 